УДК 342.9

DOI https: / / doi.org/10.32837 / yuv.v0i3.1956

\author{
Ю. Бурченко, \\ аспірантка кафедри юридичних дисциплін \\ Навчально-наукового інституту права \\ Національного університету водного господарства та природокористування
}

\title{
СУБ’ЄКТИ, ЯКІ ПРИТЯГАЮТЬСЯ ДО ВІДПОВІДАЛЬНОСТІ ЗА НЕВИКОНАННЯ УМОВ КАРАНТИНУ
}

Постановка проблеми. Недавно державні органи влади внесли зміни до вже існуючих та затвердили низку нових законодавчих актів, спрямованих на запобігання поширенню інфекційних хвороб. Ефективні заходи, спрямовані на запобігання та протидію інфекційним хворобам, $є$ необхідними для вдалого розвитку України як суверенної і незалежної, демократичної, соціальної, правової держави. Однак без наукового дослідження практичне застосування законодавства за порушення вимог карантину може бути не досить дієвим. Загалом це питання мало вивчене $\mathrm{i} \in$ актуальним як для адміністративного права, так і для громадськості.

Мета статті полягає в тому, щоб на основі дослідження українського законодавства, наукових праць здійснити комплексний аналіз суб'єктів, які притягуються до відповідальності за невиконання умов карантину.

Аналіз останніх досліджень i публікацій. Поняття «суб'єкт адміністративного правопорушення» стало предметом вивчення у працях В.В. Галунька, О.В. Бєлікової, П. Діхтієвського, О. Кузьменка, С.А. Стеценка, що стосується питання суб'єктів, які притягуються до відповідальності за невиконання умов карантину. Однак це питання не вивчалося, а досліджувалося як коментарі до певних положень КУпАП та електронних статей юристів.

Виклад основного матеріалу. Насамперед звернемо увагу, що дослі- дження суб'єктів, які притягуються до відповідальності за невиконання умов карантину, вимагає вивчення поняття «суб'єкт адміністративного правопорушення». В адміністративне законодавство України не включено норми, яка б окреслювала поняття «суб'єкт адміністративного правопорушення» чи в якій би містилися основні ознаки. КупАП містить певні статті, які поверхнево описують основні ознаки суб'єкта адміністративного правопорушення, але серед науковців немає єдиної точки зору щодо цієї проблематики.

Адміністративне законодавство України не використовує і не надає визначення поняттю «суб'єкт адміністративного правопорушення». Стосовно цього В.В. Галунько зазначає, що суб'єкти адміністративного права - це фізичні та юридичні особи, які мають публічні суб'єктивні права та юридичні обов'язки і наділені специфічними юридичними властивостями щодо їх реалізації [1, с. 89].

Погоджуємося 3 думкою О.В. Бєлікової, що суб'єктами адміністративного правопорушення визнаються фізичні й юридичні особи, які мають здатність і фактичну можливість нести юридичну відповідальність за вчинене протиправне діяння [2, c. 23].

На основі проведеного аналізу сформуємо власне визначення суб' $є$ тів, які притягуються до відповідальності за невиконання умов карантину. 
Це особи, які на момент вчинення адміністративного правопорушення набули певного віку, наділені правами та можуть нести юридичну відповідальність.

Зупинимося на класифікації суб'єктів адміністративного правопорушення. Д.В. Павленко виділяє загальні, спеціальні та особливі ознаки суб'єктів правопорушення. Загальні ознаки - це ознаки, характерні для будь-якої особи, яка вчинила адміністративне правопорушення та підлягає притягненню до адміністративної відповідальності (вік з 16 років і стан осудності); спеціальні ознаки - це ознаки, визначені конкретними складами адміністративних правопорушень, що характеризують особливості адміністративно-правового статусу особи та забезпечують диференціацію адміністративної відповідальності різних категорій осіб (наприклад, ознаки, які характеризують особливості трудової, службової діяльності, особливості поведінки в минулому тощо). Щодо особливих ознак суб'єктів адміністративних правопорушень, то, наприклад, під ними розуміють обставини, які пом'якшують або обтяжують відповідальність, виключають застосування деяких стягнень [3, с. 203-204].

Отже, можна виділити такі ознаки суб'єктів, які притягуються до відповідальності за невиконання умов карантину: загальні та спеціальні.

На думку В.В. Галунько, суб'єктами адміністративного права можуть бути:

1) індивідуальні суб'єкти - фізичні особи, які поділяються на такі групи: громадяни (володіють повним набором прав і обов'язків у державі), іноземці та особи без громадянства (мають обмеження щодо політичних прав, не виконують військового обов'язку), фізичні особи 3 іншим спеціальним статусом (скажімо, фізичні особи-підприємці чи фізична особа -водій транспортного засобу);

2) колективні суб'єкти (юридичні особи): держава, державні органи та установи, громадські об'єднання, адміністративно-територіальні одиниці та їх населення, виборчі округи, релігійні організації, промислові підприємства, іноземні підприємства тощо [1, с. 86$]$.

В. Галунько, П. Діхтієвський, О. Кузьменко, С. Стеценко зазначають, що приватним особам відведено провідну роль серед суб'єктів адміністративного права. Він класифікує приватних осіб на:

1) фізичних осіб - громадян України, іноземців, осіб без громадянства;

2) фізичних осіб-підприємців;

3) юридичних осіб приватної форми власності (підприємства, установи, господарські товариства);

4) громадські об'єднання;

5) професійні спілки;

6) політичні партії;

7) органи самоорганізації населення;

8) релігійні організації [4, с. 110].

Громадянин України - особа, яка набула громадянство України в порядку, передбаченому законами України та міжнародними договорами України згідно ст. 1 Закону України «Про громадянство України» [5]. Адміністративній відповідальності підлягають особи, які досягли на момент вчинення адміністративного правопорушення 16-річного віку відповідно до ст. 12 КУПАП [6].

У ст. 1 Закону України «Про громадянство України» міститься таке визначення поняттю «іноземець» особа, яка не перебуває в громадянстві України і є громадянином (підданим) іншої держави або держав [5]. «Особа без громадянства» - це особа, яку жодна держава відповідно до свого законодавства не вважає своїм громадянином відповідно до ст. 1 Закону України «Про громадянство України» [5].

Згідно ст. 16 КУПАП іноземці і особи без громадянства, які перебувають на території України, підлягають адміністративній відповідальності на загальних підставах з громадянами України. Питання про відповідаль-

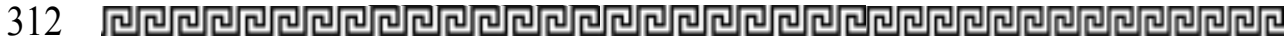


ність за адміністративні правопорушення, вчинені на території України іноземцями, які згідно 3 чинними законами та міжнародними договорами України користуються імунітетом від адміністративної юрисдикції України, вирішуються дипломатичним шляхом [6].

Основною ознакою адміністративного статусу громадянина України $€$ наявність правосуб'єктності (правоздатності, дієздатності та деліктоздатності). Громадяни не можуть відчужити свою правоздатність, адже вона може бути обмежена згідно вироку або постанови суду.

В.В. Галунько виділяє потрійний статус фізичної особи в адміністративному праві:

1) негативний статус фізичної особи - це право особистої свободи як правоможність індивіда на те, щоб влада не втручалася до сфери особистої свободи, відмежованої законом (наприклад, недоторканність житла, свобода пересування, таємниця приватного життя, листування, телефонних розмов);

2) позитивний статус особи - це обов'язок публічної адміністрації надавати фізичним і юридичним особам адміністративні послуги;

3) активний статус громадянина - це право громадян брати участь у публічній владі (сукупність політичних прав) [1, с. 90].

Ми погоджуємося 3 думкою В.В. Галунька, що фізична особа перетворюється в громадянина тільки тоді, коли повністю здобуває права цього потрійного статусу [1, с. 90].

В.В. Галунько включає до змісту адміністративно-правового статусу особи такі юридичні елементи:

1) публічні суб'єктивні права та юридичні обов'язки;

2) обсяг i характер правосуб'єктності;

3) адміністративна відповідальність;

4) у деяких випадках - дисциплінарна відповідальність посадових осіб публічної адміністрації [1, с. 91].
Натепер серед науковців залишається дискусійним питання щодо віднесення юридичних осіб до суб'єктів адміністративних правопорушень. Одні вчені вважають, що тільки фізичні особи є суб'єктами адміністративних правопорушень, інші ж дотримуються думки, що суб'єктами адміністративних правопорушень можуть бути як фізичні, так і юридичні особи. Ця проблема випливає 3 того, що в адміністративному законодавстві вживається тільки термін «особа». Тому можна допустити, що суб'єктом адміністративного правопорушення може бути й юридична особа.

3 приводу цього питання О.В. Бєлікова зазначає, що, уважно проаналізувавши норми щодо віку, після досягнення якого настає відповідальність, обставин, які виключають адміністративну відповідальність неосудної особи, мету адміністративного стягнення тощо, можна дійти висновку, що КУпАП встановлює адміністративну відповідальність лише фізичних осіб. Досліджуючи приписи наведених вище законів, які встановлюють відповідальність юридичних осіб, можна дійти висновку, що частина законів включає позначення цієї відповідальності, не передбачаючи розміру штрафних санкцій, порядку провадження у справі тощо [2, с. 26]

Ми вважаємо, що суб'єктами, які притягуються до відповідальності за невиконання умов карантину, можуть бути фізичні та юридичні особи, в тому числі фізичні особи-підприємці. Варто зауважити, що нормативні акти, які регулюють порушення вимог карантину, передбачають застосування штрафу як до юридичних осіб, так і до фізичних осіб-підприємців відповідно до постанов Кабінету Міністрів.

Фізична особа-підприємець має своєрідний адміністративно-правовий статус, що відрізняе іï від фізичної та юридичної осіб. В. Галунько, П. Діхтієвський, О. Кузьменко, 
С. Стеценко виділяють такі особливості адміністративно-правового статусу фізичної особи-підприємця:

1) первинною особливістю фізичної особи-підприємця є те, що після державної реєстрації в порядку, встановленому законом, він набуває права на здійснення підприємницької діяльності, яку не заборонено законом, та обмеження на здійснення підприємницької діяльності, що встановлюються Конституцією та законами України;

2) на підприємницьку діяльність фізичних осіб поширюються нормативно-правові акти, що регулюють підприємницьку діяльність юридичних осіб;

3) фізична особа-підприємець відповідає за зобов'язаннями, пов'язаними $з$ підприємницькою діяльністю, усім своїм майном, крім майна, на яке згідно із законом не може бути звернено стягнення, та може бути визнана банкрутом;

4) важливою рисою фізичної особи-підприємця є угодоздатність;

5) на фізичних осіб-підприемців поширюється право на захист від порушень з боку суб'єктів публічної адміністрації в процесі здійснення публічного контролю (дотримання мораторію на перевірку бізнесу) [4, c. 117].

Міністерство юстиції надало таке роз'яснення щодо статусу фізичної особи-підприємця: «Фізична особа-підприємець у цивільно-господарських відносинах $є$ різностороннім учасником. Принципи здійснення підприємницької діяльності роблять його подібним до юридичних осіб, тоді як у приватних відносинах, незважаючи на будь-які зміни в його статусі, він залишається громадянином-фізичною особою. Тому необхідно чітко розмежовувати ці різні сфери відносин».

На підставі правила, встановленого у ст. 51 Цивільного кодексу України, до фізичних осіб-підприємців слід застосовувати норми спеціального (господарського) законодавства, якщо предметом регулювання $є$ іх підприємницька діяльність. Необхідно брати до уваги й норми цивільного законодавства, якщо предмет регулювання виходить за межі підприємницької діяльності, зачіпаючи приватні інтереси суб'єкта, та повністю врегульовується нормами Цивільного кодексу України [7].

3 приводу цього питання В. Галунько, П. Діхтієвський, О. Кузьменко, С. Стеценко наводять таке визначення адміністративно-правовому статусу особи-підприємця - це порядок і підстави легалізації приватної особи в цьому статусі, а також сукупність прав вільно здійснювати підприємницьку діяльність, не порушуючи заборонних норм адміністративного (господарського) права, що підкріплено обов'язком публічної адміністрації надавати сервісні послуги для ефективного розвитку підприємницької діяльності та дотримання обмежень щодо міри і ступеня втручання у сферу підприємницької свободи [4, с. 117].

Варто звернутися до ст. 44-3 КУпАП, де зазначено, що «порушення правил щодо карантину людей, санітарно-гігієнічних, санітарно-протиепідемічних правил і норм, передбачених Законом України «Про захист населення від інфекційних хвороб», іншими актами законодавства, а також рішеннями органів місцевого самоврядування 3 питань боротьби 3 інфекційними хворобами тягне за собою накладення штрафу на громадян від однієї до двох тисяч неоподатковуваних мінімумів доходів громадян і на посадових осіб - від двох до десяти тисяч неоподатковуваних мінімумів доходів громадян [6].

Проаналізувавши цю норму, можна зробити висновок, що за порушення вимог карантину покарання застосовується до громадян і посадовців-юридичних осіб чи фізичних осіб-підприємців. У цьому випадку при складанні протоколу уповноважена особа повинна правильно

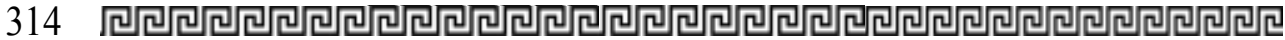


визначити суб'єкта адміністративного правопорушення.

Стосовно цього питання наведемо судову статистику. Як повідомляє прес-служба Зарічного районного суду м. Сум, суд закрив провадження у трьох справах за фактом порушення правил щодо карантину людей. Розглянемо ці судові справи. Так, 24 березня 2020 року у зв'язку 3 відсутню складу адміністративного правопорушення за ст. 44-3 КУпАП (порушення правил щодо карантину людей) суд закрив провадження по справі стосовно продавця зоомагазину. Згідно протоколу 20 березня 2020 року жінка, будучи продавцем у зоомагазині, здійснювала прийом покупців, чим скоїла правопорушення, передбачене ст. 44-3 КУпАП. За цим фактом було складено протокол про адміністративне правопорушення.

У судовому засіданні жінка провину не визнала та пояснила, що $€$ найнятим працівником. 3 письмових доказів, долучених до протоколу, вбачається, що жінка працює на ФОП А., який і $є$ безпосереднім суб'єктом господарювання, що здійснював відповідну діяльність, наведену в протоколі. Беручи до уваги, що жінка $є$ лише працівником, а не безпосереднім суб'єктом, який здійснював згадану в протоколі діяльність, у розумінні ст. 44-3 КУпАП вона не $€$ суб'єктом вказаного правопорушення [8].

У зв'язку з відсутню складу адміністративного правопорушення за ст. 44-3 КУПАП суд також закрив провадження у справі стосовно продавця магазину іграшок. Жінка є лише працівником, а не безпосереднім суб'єктом, який здійснював господарську діяльність 3 продажу іграшок. Тому в розумінні ст. 44-3 КУПАП вона не є суб'єктом вказаного правопорушення [8].

Також у зв'язку з відсутню складу адміністративного правопорушення за ст. 44-3 КУПАП суд закрив провадження по справі стосовно директора
TOВ. Згідно протоколу 19 березня 2020 року чоловік, будучи директором ТOB, не припинив роботу кіоску «Блинок» у місті Суми, чим скоїв правопорушення, передбачене ст. 44-3 КУпАП. У судовому засіданні захисник заперечила проти складеного протоколу, вважаючи, що неправильно визначений суб'єкт адміністративного правопорушення, оскільки на час складання протоколу чоловік не здійснював господарської діяльності в наведеному приміщенні, а кіоск був переданий ще в серпні 2019 року в оренду іншій особі. На підтвердження цього були надані відповідні документи. Будь-яких доказів на підтвердження тих обставин, що саме чоловік, на якого складено протокол, здійснював наведену діяльність ані протокол, ані долучені до нього документи не містять взагалі [8].

Можна зробити висновок, що у правозастосуванні накладання штрафної санкції на юридичну особу чи на фізичну особу-підприємця є проблематичною з точки зору встановлення суб'єкта правопорушення. Науковці не досягли єдиної точки зору 3 цього питання. Характеристика різних тверджень як прихильників, так і противників адміністративної відповідальності юридичних осіб демонструє, що в кожної зі сторін $€$ підтвердження своїх ідей.

Ми не погоджуємося 3 твердженням, що «в адміністративному праві може існувати комплексне розуміння вини юридичної особи, що включає об'єктивний і суб'єктивний підходи. Об'єктивна вина - це вина організації з точки зору державного органу, який застосовує адміністративне покарання залежно від характеру конкретних дій або бездіяльності юридичної особи, що порушує встановлені правила; суб'єктивна вина - ставлення організації в особі їі колективу, адміністрації, посадових осіб до протиправного діяння» [2, с. 26]. Це свідчить про те, що постійні згадування цих понять і встановлена законодавством 
адміністративна

відповідальність такого суб'єкта, як фізична особа-підприємець, відсутні у Главі 5 «Адміністративні правопорушення в галузі охорони праці і здоров'я населення».

3 огляду на те, що нормативні акти встановлюють адміністративну відповідальність фізичних осіб-підприємців за порушення вимог карантину, ми пропонуємо внести до Кодексу України про адміністративні правопорушення статтю у такій редакції: посадові особи, які уповноважені здійснювати підприємницьку діяльність, як учасники правових відносин, піддаються адміністративній відповідальності за порушення вимог карантину на основі законодавства України.

Фізична та юридична особи, в тому числі фізична особа-підприємець, повинні мати правосуб'єктність для того, щоб бути суб'єктом адміністративного правопорушення. Лише володіння правосуб'єктністю надає суб'єкту право бути учасником адміністративних правовідносин. Для юридичної особи правосуб'єктність виражається в об'єднанні прав та обов'язків, які відображають втілення функцій відповідно до мети та завдань підприємства, установи, організації, записаних в установчому договорі.

3 цього питання В.В. Галунько відстоює думку, що для юридичних осіб правосуб'єктність єдина, вона виникає з моменту створення (державної реєстраціі), припиняється 3 моменту виключення юридичної особи з державного реєстру, має спеціальний характер [1, с. 89].

Ми погоджуємося з думкою О.В. Бєлікової, що до суб'єктів адміністративних правопорушень належать фізичні і юридичні особи, незалежно від організаційно-правових форм і форм власності. Їх об'єднує те, що всі вони володіють особливою юридичною якістю - адміністративною правоздатністю, тобто здатністю отримувати відповідний комплекс юридичних прав і обов'язків адмі- ністративно-правового характеру й нести відповідальність за їх реалізацію. Для того, щоб суб'єкт адміністративного права став учасником адміністративно-правових відносин, він повинен мати адміністративну деліктоздатність, тобто практичну здатність реалізовувати свою адміністративну правоздатність у рамках конкретних адміністративно-правових відносин [2, с. 23].

Висновки. Узагальнюючи зазначене вище, зауважимо, що адміністративна відповідальність за порушення вимог карантину має широке коло суб'єктів, яким забезпечено законодавством права і обов'язки. $\mathrm{У}$ дослідженні доведено, що фізичні та юридичні особи (в тому числі й фізичні особи-підприємці) можуть бути суб'єктами адміністративного правопорушення за порушення вимог карантину.

Зазначимо, що адміністративна відповідальність за порушення вимог карантину накладається на посадових осіб, уповноважених здійснювати підприємницьку діяльність. Здійснений аналіз дав можливість дійти висновку, що уповноважені органи при накладанні адміністративного стягнення не правильно визначають суб'єктів адміністративного правопорушення за порушення вимог карантину, що призводить до того, що суди закривають провадження у справах.

Дослідження присвячене вивченню суб’єктів, які притягуються до відповідальності за невиконання умов карантину. У статті наводяться думки різних науковциів щзодо визначення поняття «суб'єкт адміністративного правопорушення». Зазначено, що в адміністративному праві немає терміну «суб'єкт адміністративного правопорушення». Автор статті формуе таке визначення «суб”єктів, які притягуються до відповідальності за невиконання умов карантину». Це особи, які на момент вчинення адміністративного 
правопорушення набули певного віку, наділені правами та можуть нести юридичну відповідальність. Наведені характерні ознаки, притаманні суб'єктам адміністративних правопорушень. Автором статті сформовані суб'єкти, які безпосередньо стосуються правопорушень щодо порушення вимог карантину.

Окрему увагу приділено питанню, чи може юридична особа, в тому числі й фізична особа-підприємецьь, бути суб'єктом адміністративних правопорушень. Автор статті дотримується думки, що нормативні акти встановлюють адміністративну відповідальність фізичних осіб-підприемців за порушення вимог карантину, тому пропонуе внести до Кодексу України про адміністративні правопорушення статтю у такій редакиії: посадові особи, уповноважені здійснювати підприємницьку діяльність, як учасники правових відносин, піддаються адміністративній відповідальності за порушення вимог карантину на основі законодавства України.

3'ясовано, що фізична та юридична особи, в тому числі фізична особа-підприємець, повинні мати правосуб'єктність для того, щзоб бути суб'єктом адміністративного правопорушення. Лише володіння правосуб'єктністю надає суб'єкту право бути учасником адміністративних правовідносин.

Зроблено висновок, що при правозастосуванні, а саме накладанні итрафної санкції на юридичну особу чи на фізичну особу-підприємия, $є$ проблематичним встановлення суб'єкта правопорушення. На підтвердження иієї думки автор наводить судову статистику щодо закриття провадження по справах за неправильне визначення суб'єктів адміністративних правопорушень.

Ключові слова: суб'єкт правопорушення, карантин, відповідальність, фізична особа-підприємець, посадова особа.
Burchenko Yu. Entities brought to liability for failure to comply with quarantine conditions

The study examines subjects who are prosecuted for non-compliance with quarantine conditions. The article presents the opinions of various scholars on the definition of "subject of administrative offense". It is noted that administrative law does not contain the term "subject of an administrative offense". The author of the article forms the following definition of "subjects who are prosecuted for non-compliance with the conditions of quarantine".

These are persons who, at the time of the commission of an administrative offense, have reached a certain age, are endowed with rights and may bear legal responsibility. The characteristic features that are inherent in the subjects of administrative offenses and the author of the article formed subjects that are directly related to the offenses of violation of quarantine requirements. Particular attention is paid to the question of whether a legal entity, including an individual entrepreneur, can be the subject of administrative offenses.

The author of the article is of the opinion that regulations establish administrative liability of natural persons entrepreneurs for violation of quarantine requirements, so he proposes to include an article in the Code of Administrative Offenses in the following wording: officials authorized to conduct business as participants in legal relations are subject to administrative liability for violation of quarantine requirements based on the legislation of Ukraine. It was found that natural and legal persons, including natural personsentrepreneurs, must have legal personality in order to be the subject of an administrative offense.

Only the possession of legal personality gives the subject the right to be a party to an administrative 
legal relationship. It is concluded that in law enforcement, namely the imposition of a penalty on a legal entity or an individual entrepreneur is problematic in terms of establishing the subject of the offense. In support of this view, the author provides court statistics on the closure of proceedings in the case for incorrect identification of the subjects of administrative offenses.

Key words: subject of the offense, quarantine, liability, individual entrepreneur, official.

\section{Література}

1. Адміністративне право України. T. 1. Загальне адміністративне право: навчальний посібник / /В.В. Галунько, В.І. Курило, С.О. Короєд, О.Ю. Дрозд, I.В. Гиренко, О.М. Єщук, I.М. Риженко, А.А. Іванищук, Р.Д. Саунін, І.М. Ямкова); за ред. проф. В.В. Галунька. Херсон: Грінь Д.С. 2015. 272 с.

2. Белікова О.В. Юридичний склад адміністративного правопорушення. Держава та регіони. Серія: Право. 2013. № 3(41). С. 22-27.

3. Павленко Д.В. Суб'єкти адміністративних правопорушень під час здійснення публічно-сервісної діяльності в аграрному секторі економіки України.
Науковий вісник Національного універсиmету біоресурсів і природокористування України. 2013. Bun. 182. Ч. 3. С. 202-212.

4. Адміністративне право України. Повний курс : підручник. Галунько В., Діхтієвський П., Кузьменко О., Стеценко С. та інші. Херсон : ОЛДІ-ПЛЮС. 2018. 446 c.

5. Закон України «Про громадянство України» станом на 25.08.2019 / Верховна Рада України від 2001 № 13. URL: https: / / zakon.rada.gov.ua/laws/ show/2235-14\#Text (дата звернення: 22.06.2020)

6. Кодекс України про адміністративні правопорушення станом на 14.05.2020 / Верховна Рада України від 07.12.1984 № 8074-10. URL: https: / / zakon.rada.gov.ua/ laws/show/80731-10 (дата звернення: 22.06.2020).

7. Роз'яснення Міністерства юстиції України «Статус фізичної особи-підприємия: проблеми застосування законодавства» від 14.01.2011. URL: https: / / zakon.rada.gov.ua/laws / show / n0012323-11\#Text (дата звернення: 22.06.2020).

8. Зарічний районний суд м. Сум закрив провадження у трьох справах за фактом порушення правил щодо карантину / Судова влада Українu. URL: https://court.gov.ua/press / пеше /915081/ (дата звернення: 22.06.2020). 